\title{
Optimalisasi Regulasi Jaminan Produk Halal \& Sertifikasi Halal LPPOM MUI untuk Produk Minuman Herbal
}

\author{
Fitria Esfandiari ${ }^{1}$ Sholahuddin Al-Fatih ${ }^{2 *}$ \\ 1,2 Fakultas Hukum, Universitas Muhammadiyah Malang \\ Email: fit.esfan@gmail.com, sholahuddin.alfath@gmail.com \\ *Corresponding author: sholahuddin.alfath@gmail.com
}

\begin{abstract}
ABSTRAK
Produk halal saat ini telah menjadi gaya hidup bagi seluruh masyarakat di dunia, tak terkecuali di Indonesia. Sebagai bagian dari tren dan gaya hidup tersebut, beberapa UMKM dan home industry mencoba merespon dengan tekun mempelajari regulasi terkait jaminan produk halal. Tak hanya itu saja, para pelaku usaha juga mulai rajin mempelajari alur pengajuan sertifikasi halal oleh LPPOM MUI. Pengabdian ini berusaha menjembatani kebutuhan tersebut. Melalui model pengabdian langsung dengan mode blended learning, tim pengabdi dari Fakultas Hukum Universitas Muhammadiyah Malang memberikan edukasi dan ilmu raktis kepada Mitra, yaitu CV. Caraka Abadi, produsen minuman herbal Cangloh. CV. Caraka Abadi berdomisili di Kota Malang dengan membawahi beberapa merek produk herbal, terutama minuman herbal. Hasil pengabdian menghasilkan dokumen pengajuan sertifikasi halal LPPOM MUI yang sudah disetujui dan tingal menunggu penerbitan serta pemahaman karyawan CV. Caraka Abadi tentang regulasi jaminan produk halal.
\end{abstract}

Kata Kunci: Halal, Herbal, LPPOM, MUI, Product

\begin{abstract}
Halal products have now become a lifestyle for all people in the world, including in Indonesia. As part of these trends and lifestyles, several MSMEs and home industries are trying to respond by diligently studying regulations related to halal product guarantees. Not only that, business actors have also begun to diligently study the flow of filing for halal certification by LPPOM MUI. This dedication seeks to bridge these needs. Through a direct service model with blended learning mode, the service team from the Faculty of Law, University of Muhammadiyah Malang provides education and practical knowledge to partners, namely CV. Caraka Abadi, producer of Cangloh herbal drink. $C V$. Caraka Abadi is domiciled in Malang City and oversees several brands of herbal products, especially herbal drinks. The results of the service resulted in the LPPOM MUI halal certification application document that had been approved and was just waiting for the issuance and understanding of $\mathrm{CV}$ employees. Caraka Abadi regarding regulations on halal product guarantees.
\end{abstract}

Keyowrds: Halal, Herbal, LPPOM, MUI, Product 


\section{PENDAHULUAN}

Kota Malang dikenal sebagai

kota pendidikan. Sebagai kota pendidikan, ribuan mahasiswa dan siswa hadir dari berbagai daerah (Yuliana, 2016). Potensi tersebut ikut mendorong pertumbuhan ekonomi di Kota Malang. Berdasarkan data BPS, laju pertumbuhan ekonomi Kota Malang tumbuh sebesar 5,73\% pada tahun 2019 lalu (BPS, 2020).

Sektor industri kreatif menjadi salah satu penyumbang pertumbuhan perekonomian di Kota Malang (Zain et al., 2021). Banyaknya orang dari luar daerah yang datang ke Kota Malang, membuat mereka membutuhkan buah tangan atau oleh-oleh yang bisa dibawa ke kampung halaman (Salam et al., 2021). Salah satunya adalah melalui minuman khas Kota Malang dan juga kripik tempe di wilayah Sanan yang menjadi sentra industri rumah tangga produktif.

Selain Sanan, kini mulai tumbuh pula beberapa industri rumah tangga yang menghasilkan produk sebagai buah tangan khas Kota Malang. Salah satunya adalah CV. Caraka Abadi yang memproduksi minuman herbal Cangloh. CV. Caraka Abadi sebelumnya memakai nama PJ Caraka atau Perusahaan Jamu Caraka. Namun, seiring dengan perubahan zaman, Caraka mengubah status hukumnya menjadi CV.

Tingginya permintaan pasar membuat dinamika dan perubahan status badan hukum Caraka menjadi sebuah hal yang mutlak untuk dilakukan. Industri rumah tangga yang berlokasi di wilayah Mergosono, Gadang, Kota Malang tersebut kini telah memperoleh beberapa capaian, diantaranya Nomor P-IRT, uji laboratorium BPOM, pendaftaran merk Canglohke Dirjen HKI serta mendapatkan dana hibah dari Paguyuban Posdana Bumiayu.

Sayangnya, sebagai produk utama yang di produksi oleh CV. Caraka Abadi, minuman dengan merk Cangloh tersebut belum bisa mendapatkan akses akad halal dari MUI (LPPOM MUI, 2008). Padahal, akad dan sertifikasi halal dari MUI bisa menjadi sebuah rekognisi yang bisa menambah kepercayaan konsumen (Sholahuddin Al-Fatih \& Esfandiari, 2020). Sayangnya, memang saat ini di pasaran tidak semua produsen menyediakan produk, baik makanan maupun minuman yang berlabel sertifikasi halal MUI (Sa'diyah, 2017).

Permasalahan yang timbul dari ketiadaan akad dan logo halal MUI dikarenakan keyakinan yang dianut oleh founder sekaligus owner CV. Caraka Abadi yang merupakan penganut Agama Kepercayaan Sapta Dharma (Anonim, 2021). Meskipun demikian, dua orang anak dari founder dan owner CV. Caraka Abadi telah berpindah keyakinan dan menganut agama Islam. Hal ini bisa menjadi potensi bagi CV. Caraka Abadi untuk ke depan bisa mendaftarkan dan melaksanakan akad halal di kantor MUI. 
Meskipun demikian, butuh proses yang tidak sebentar untuk penjaminan produk halal dalam industri yang dikelola oleh CV. Caraka Abadi.

Pegawai dan pihak terkait perlu diberikan pendampingan agar saat kunjungan ke lokasi mereka bisa memastikan bahwa semua bahan baku pembuatan Cangloh adalah berstatus halal. Kedua anak dari owner dan founder CV. Caraka Abadi juga membutuhkan pendampingan karena status mereka muallaf yang baru saja memahami dan mempelajari agama Islam, sehingga edukasi terkait produk halal berdasarkan UndangUndang Jaminan Produk Halal sangat penting untuk dilakukan (Wiryani et al., 2018).

Melihat kondisi tersebut, pengabdi yang berasal dari Fakultas Hukum Universitas Muhammadiyah, terdiri dari Sholahuddin Al-Fatih dan Fitria Esfandiari, serta dibantu dengan 5 orang mahasiswa yang ikut melaksanakan PMM (Program Mahasiswa Mengabdi) Mitra Dosen, memilih CV. Caraka Abadi sebagai mitra pengabdian masyarakat.

Tujuan dari dilakukannya pengabdian ini adalah jelas untuk membantu CV. Caraka Abadi agar bisa mengajukan sertifikasi halal dari LPPOM MUI untuk produk minuman herbal Cangloh. Selain itu, pegawai CV. Caraka Abadi juga perlu mendapatkan edukasi terkait regulasi jaminan produk halal.

\section{METODE PENELITIAN}

Metode penelitian lazim digunakan dalam sebuah penelitian ilmiah, tak terkecuali dalam melakukan pengabdian kepada masyarakat. Adapun metode pengabdian yang digunakan pada pengabdian ini antara lain :

1. Kuesioner

Kuesioner merupakan salah satu cara atau metode pengumpulan informasi dalam jumlah besar yang relatif cepat, murah, dan efisien. Kuesioner biasanya berisi pertanyaan yang nantinya akan dijawab oleh para responden. Jawaban dari para responden tadi kemudian dikumpulkan, dianalisis dan ditarik sebuah kesimpulan (Irwansyah, 2020).

Dengan menggunakan metode ini peneliti dapat mendapakan data dari sampel banyak orang. Keisioner ini ditujukan pada keluarga besar CV. Caraka Abadi dan UMKM yang bertempat di RT 11 /RW 01 Kelurahan Bumiayu, Kecamatan Kedungkandang, Kota Malang Daftar pertanyaan tersebut dibuat cukup terperinci dan lengkap. Kuesioner yang berikan merupakan pertanyaanpertanyaan yang meliputi jaminan produk halal serta pengurusan sertifikasi halal.

Melalui kuesioner nantinya akan diperoleh hasil tentang sejauh mana pemahaman $\mathrm{CV}$. Caraka Abadi dan juga UMKM 
setempat tentang jaminan produk halal dan pengurusan sertifikasi halal.

\section{Penyuluhan}

Penyuluhan merupakan salah satu metode yang digunakan untuk memberi pengetahuan, informasi maupun hal-hal baru lainnya kepada masyarakat agar mereka tertarik, bersedia dan berminat untuk menerapkannya dalam kehidupan sehari-hari (Soekanto, 2014).

Penyuluhan dilakukan sebanyak 2 kali dengan tetap memperhatikan protokol kesehatan. Materi yang disampaikan dipenyuluhan pertama tentang Pengertian dan Dasar Hukum Jaminan Produk Halal yang didalamnya juga terdapat pengurusan sertifikasi halal serta Kriteria Sistem Jaminan Produk Halal untuk penyuluhan kedua.

\section{Sharing}

Dua metode diatas kemudian dikombinasi dengan model sharing secara langsung dengan pegawai CV. Caraka abadi. Sharing dilakukan utnuk melihat seberapa besar pemahaman mitra terhadap materi yang sudah disampaikan melalui penyuluhan.

Sehingga, melalui kombinasi dari ketiga metode, diharapkan pengabdian ini benar-benar memberikan manfaat tidak hanya bagi mitra tapi juga bagi pengabdi.

\section{Publikasi}

Metode yang terakhir adalah melalui publikasi. Pengabdian ini direncanakan akan dipublikasikan di Jurnal Ilmiah Nasional dan media elektornik. Publikasi dipandnag oleh pengabdi sebagai cara efektif untuk ikut memberikan edukasi terkait tren dan gaya hidup produk halal.

\section{HASIL DAN PEMBAHASAN}

Pengabdian ini dengan metode penyuluhan memberikan hasil berupa pemahaman stakeholders CV. Caraka Abadi, baik owner maupun karyawannya tentang Pengertian dan Dasar Hukum Jaminan Produk Halal sesuai dengan ketentuan dalam Undang-Undang Jaminan Produk Halal. Termasuk di dalam penyuluhan yang pertama, stakeholders mendapatkan hadiah dari pengabdi berupa SOP sesuai dengan ketentuan Undang-Undang Jaminan Produk Halal.

Hasil yang kedua dengan
metode pendampingan yakni
pengurusan sertifikasi halal serta
Kriteria Sistem Jaminan Produk
Halal. Dalam hasil yang kedua
tersebut, pengabdi turut membantu
CV. Caraka Abadi dalam emmenuhi
standar dan syarat pengajuan
sertifikasi halal LPPOM MUI dan
BPJPH.

Cangloh merupakan minuman herbal yang dibuat dari dua bahan 
utama, yaitu secang (seperti kayu manis) dan blimbing wuluh. Selain menyegarkan, Cangloh juga memiliki khasiat yang telah teruji secara klinis, seperti menambah nafsu makan maupun melancarkan BAB. Berikut gambaran produk Cangloh beserta analisis keuangannya.

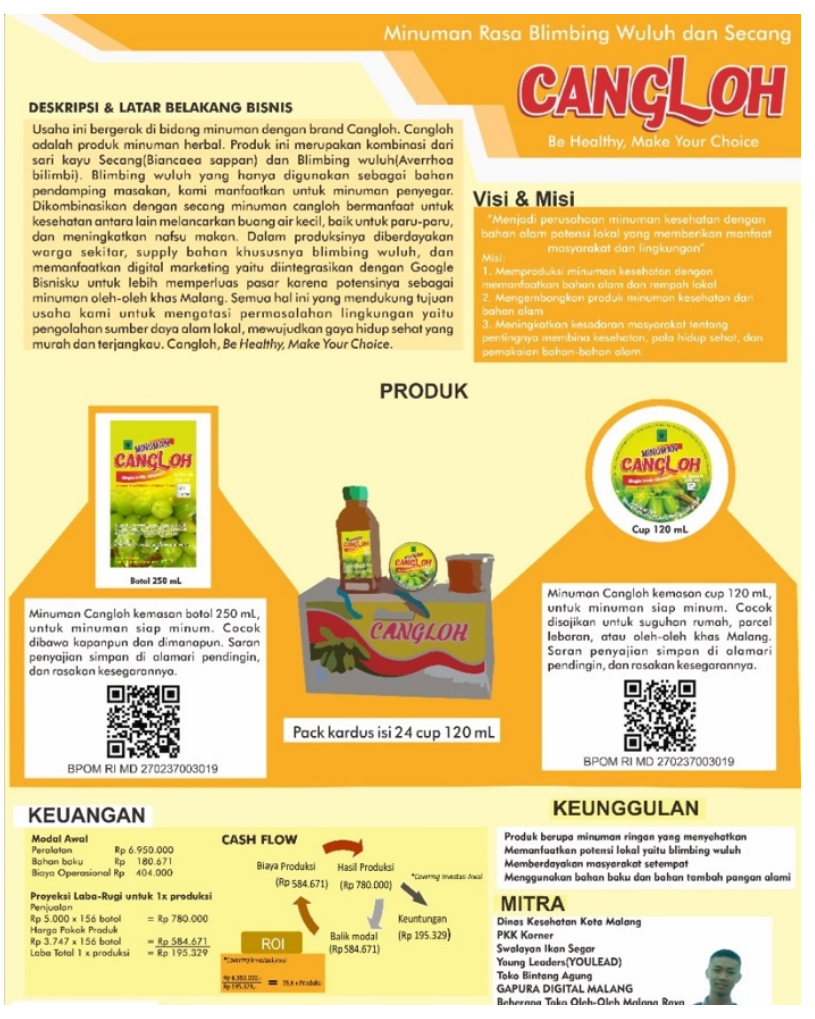

Gambar 1. Infografis Cangloh

\begin{abstract}
Apabila dilihat dari komposisi bahan pembuatnya, Cangloh akan secara mutlak bisa disebut sebagai minuman halal. Karena jelas baik secara dhahir dan bathin, tidak ada unsur haram dalam komposisi bahan pembuat Cangloh tersebut. Namun, apakah cukup dengan bahan yang halal lantas sebuah produk bisa disebut hala dan berhak mendapatkan sertifikasi halal dari LPPOM MUI.
\end{abstract}

Oleh karenanya, perlu memahami regulasi tentang jaminan produk halal, agar tidak terjebak pada paradigma dan klaim atas kehalalan sebuah produk. Menurut UndangUndang Nomor 33 Tahun 2014 tentang Jaminan Produk Halal (UU JPH), pengertian produk halal adalah produk yang telah dinyatakan halal dan sesuai dengan syariat islam (S. Al-Fatih \& Aditya, 2017). Sedangkan pengertian Jaminan Produk Halal (JPH) adalah kepastian hukum terhadap kehalalan suatu produk yang dibuktikan dengan adanya sertifikat halal (Sayekti, 2014). Adapun makanan yang diharamkan didalam Al-Qur'an anatara lain yaitu:

1. Bangkai;

2. Darah;

3. Babi;

4. Daging hewan yang disembelin dengan nama selain Allah SWT;

5. Khamr/minuman keras;

6. Dsb.

Sebenarnya segala sesuatu yang terdapat di muka bumi ini huku asalnya adalah halal, kecuali hal-hal yang dilarang didalam Hadist dan AlQur'an seperti yang telah diuraikan diatas. Seiring dengan berkembangnya teknologi, produkproduk khususnya produk makanan dan minuman patut dipertanyakan kehalalannya. Sebab saat ini banyak produsen makanan dan minuman yang menggunakan bahan-bahan haram pada bahan baku produknya, baik itu bahan baku tambahan maupun bahan baku utama yang 
bertujuan untuk meraup untung sebesar-besarnya karena dianggap lebih ekonomis.

Selain itu masih banyaknya perushaan yang mengelola produk makanan maupun minuman yang mengabaikan kebersihan dalam pengelolaannya. Menanggapi hal tersebut Majelis Ulama Indonesia (MUI) memberi fatwa bahwa semua produk olahan pada dasarnya adalah syubhat. Maka dari itu dibutuhkan kajian yang mendalam sebelum mentetapkan status kehalalan dalam suatu produk khususnya produk makanan dan minuman yang beredar di Indonesia yang mana hal ini dilakukan demi keamanan dan kenyamanan konsumen khususnya konsumen muslim (Sayekti, 2014).

Kedua realita tersebut, yang saling bertolak belakang dna butuh ilmu pengetahuan, menjadi modal awal bagi tim pengabdi dari Fakultas Hukum Universitas Muhammadiyah Malang untuk melakukan pengabdian di lokasi mitra dengan menerapkan prokes yang sangat ketat.

Pengabdian ini bertempat di CV. Caraka Abadi yang terletak Jalan Kyai Parseh Jaya Gang Kenikir Indah RT 11/ RW 01 Kelurahan Bumiayu, Kecamatan Kedungkandang, Kota Malang. Cv. Caraka Abadi merupakan salah satu perusahaan yang mengelola produk herbal salah satunya minuman Cangloh.

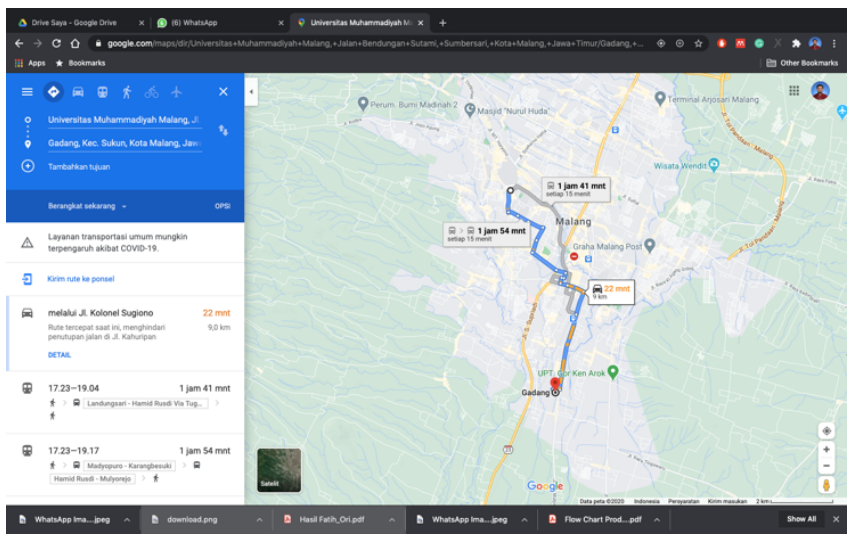

Gambar 2. Lokasi Mitra dan Jarak dengan Institusi Pengabdi

Sebagaimana telah disebutkan sebelumnya, Cangloh merupakan minuman herbal yang berbahan utama buah belimbing wuluh dan secang. Minuman ini memiliki banyak manfaat serta tidak memiliki efek samping sehingga aman dikonsumsi oleh semua kalangan usia, mulai dari anak balita sampai dengan lansia.

Pengabdian ini merupakan pendampingan serta memberikan edukasi dengan cara sosialisasi kepada CV. Caraka Abadi tentang jaminan produk halal dan pengurusan sertifikasi halal. Sebagaimana yang kita ketahui halal merupakan istilah yang berasal dari Al-Quran dan seringkali digunakan untuk membahas yang berkaitan dengan produk makanan dan minuman.

Secara Bahasa, halal berasal dari kata halla - yahillu - hillan yang artinya membolehkan. Secara terminologi, halal memiliki dua makna, yaitu segala hal yang tidak 
dilarang dan dihukum ketika menggunakannya dan sesuatu yang diperbolehkan menurut syari'at. Dalam konteks makanan dan minuman, kata halal memiliki arti segala sesuatu yang diperbolehkan oleh syari'at, sehingga boleh dikonsumsi dan aman untuk didistribusikan (Awaludin, 2018).

Adapun dasar kewajiban untuk mengkonsumsi makanan yang halal terdapat dalam Al-Qur'an surat Al-Baqarah/2:168 yang berbunyi:

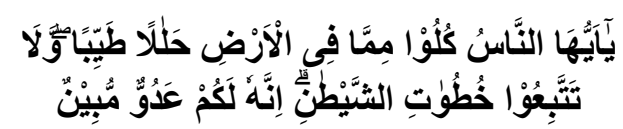

Artinya: Wahai manusia, makanlah dari (makanan) yang halal lagi baik yang terdapat di bumi, dan janganlah kamu mengikuti langkah-langkah setan. Sungguh setan itu musuh yang nyata bagimu. (QS. AlBaqarah/2:168).

Al-Qur'an tidak hanya memperhatikan aspek halal atau haram dalam makanan, melainkan juga memperhatikan aspek Thayyib. Menurut ar-Razi, secara Bahasa Thayyib memiliki arti suci. Thayyib merupakan makanan-makanan yang bergizi sesuai dengan kondisi yang memakan makanan tersebut. Selain itu, definisi lain dari makanan Halal dan Thayyib adalah makanan baik yang dapat mengandung zat-zat yang diperlukan oleh tubuh sehingga menjadikan manusia menjadi sehat dan kuat (Esfandiari \& Al-Fatih, 2021)(Sholahuddin Al-Fatih \& Aditya, 2019).

Masih banyaknya masyarakat yang tidak memahami bagaimana pentingnya label produk halal dalam suatu produk yang diproduksi dan juga pengurusan sertifikasi halal, menggerakkan dosen dan mahasiswa pengabdi untuk melakukan sosialisasi kepada CV. Caraka Abadi dan UMKM yang berada tidak jauh dari tempat pengabdian.

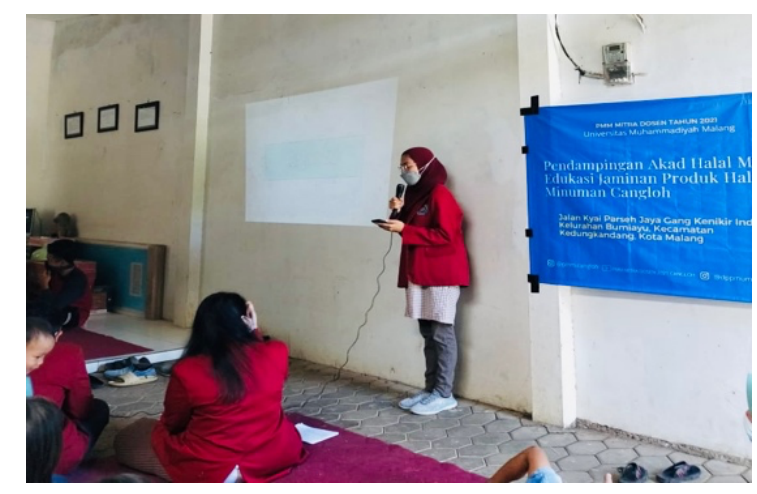

Gambar 3. Penyampaian Sosialisasi tentang Jaminan Produk Halal kepada CV. Caraka Abadi

Pada sosialisasi pertama, pengabdi memberikan pretest berupa kuisioner yang didalamnya terdapat pertanyaan berkaitan dengan jaminan produk halal. Hasil kuisioner menyatakan bahwa 90\% karyawan CV. Caraka Abadi dan juga UMKM setempat yang ikut dalam sosialisasi tentang jaminan produk halal masih belum mengetahui apa itu jaminan produk halal dan memahami manfaat dari adanya label produk halal dalam sebuah produk. 
Dalam kesempatan ini pengabdi menjelaskan bahwa Jaminan Produk Halal (JPH) mengatur dan mengawasi barangbarang yang beredar di masyarakat seperti makanan, kosmetik, dan produk-produk yang mengandung kimia. Secara teknis, penanggung jawab dalam penyelenggaraan penjaminan produk halal ini dilakukan oleh pemerintah melalui Menteri Agama dengan membentuk Badan Penyelenggaraan Jaminan Produk Halal (BPJPH) yang bertanggung jawab kepada Menteri Agama (Hidayat \& Siradj, 2015). BPJH mempunyai beberapa kewenangan seperti:

1. Menetapkan

Standar Operasional Prosedur Jaminana Produk Halal;

2. Membuat dan menetapkan kebijakan Jaminan Produk Halal;

3. Melakukan pendataan mengenai kehalalan produk yang berasal dari luar negeri;

4. Merilis dan mencabut sertifikat halal pada produk;

5. Melakukan sosialisasi dan publikasi terkait pentingnya produk halal;

6. Melakukan penilaian secara berkala kepada Lembaga Penjamin Halal (LPH), lisensi auditor produk halal; dan
7. Melakukan kolaborasi dengan lembaga luar yang menangani jaminan produk halal.

Dalam melaksanakan tugasnya, BPJPH berkolaborasi dengan Lembaga Pemeriksa Halal (LPH) dan Majelis Ulama Indonesia (MUI) (Syafrida. Hartati, 2019). Kolaborasi antara BPJH dengan LPH dilakukan di ruang lingkup pemeriksaan dan/atau pengujian produk (S. Al-Fatih \& Aditya, 2017). Sedangkan kolaborasi antara BPJPH bersama MUI yakni dalam bentuk lisensi ausditor produk halal, mengesahkan kehalalan pada produk, dan melakukan penilaian terhadap kelayakan LPH.

Dari penyampaian sosialisasi tersebut terdapat keterangan langsung dari owner CV. Caraka Abadi bahwa masih terdapat beberapa karyawan yang abai terhadap pentingnya kebersihan dalam mengelola produk. Sebagaimana yang kita ketahui bahwa kebersihan produk sangat penting untuk menjamin kualitas produk yang diproduksi. Mengingat jaminan produk halal mengawasi barang-barang yang beredar dimasyarakat, sehingga minuman cangloh yang diproduksi oleh CV. Caraka Abadi harus menjamin keamanan, kebersihan dan kualitasnya sebelum disebarluaskan.

Sosialisasi pertama berlangsung selama kurang lebih 30 menit, mengingat kondisi pandemi Covid-19 saat ini sehingga cukup 
membatasi pengabdi dalam menyampaikan materi. Dengan waktu yang terbatas tersebut selain menjelaskan bagaimana jaminan produk halal, juga menjelaskan terkait alur dari pengurusan sertifikasi halal dengan media video.

Hal ini cukup membantu dalam penyampaian sosialisasi agar peserta yang hadir dalam sosialisasi tidak bosan serta lebih menarik perhatian para peserta. Antusiasme para peserta sosialisasi sangat dirasakan dengan adanya beberapa pertanyaan tentang pengurusan sertifikasi halal. Bahkan terdapat UMKM yang tergerak untuk segera melakukan pengurusan sertifikasi halal pada produk yang dikelolanya.

Sebagai lanjutan dari sosialisasi pertama, pengabdi melakukan sosialisasi kedua. Sosialisasi kedua hanya dihadiri oleh owner dan karyawan CV. Caraka Abadi. Sosialisasi kedua ini lebih pada menjelaskan kriteria jaminan produk halal dan pentingnya kebersihan dalam proses produksi. Selain itu pengabdi juga mereview kembali materi yang sudah disampaikan pada sosialisasi pertama dan para karyawan CV. Caraka Abadi cukup antusias dalam menjawab pertanyaan yang diberikan.

Dengan adanya sosialisasi tersebut diharapakan dapat membantu para UMKM dan CV. Caraka Abadi dalam proses produksi yang dikelolanya dengan tetap memperhatikan standarisasi yang telah ditentukan oleh MUI. UndangUndang Jaminan Produk Halal (UUJPH) diharapkan dapat menjadi acuan bagaimana suatu produk dijamin kehalalannya yang meliputi penyediaan bahan baku, pengolahan, pengemasan, penyimpanan, pendistribusian, penjualan, dan penyajian produk.

$\begin{array}{llr}\begin{array}{c}\text { Proses } \\ \text { dilakukan }\end{array} & \begin{array}{c}\text { standarisasi ini } \\ \text { bertujuan }\end{array}\end{array}$
memberikan keamanan, kenyamanan, keselamatan, dan kepastian dalam menggunakan atau mengonsumsi produk yang beredar di masyarakat. Saat ini Selain itu, harapan dari diterbitkannya UUJPH ini adalah produsen dapat meningkatkan nilai jual produknya dan dapat menambah rasa kepercayaan kepada masyarakat bagi konsumennya.

Sebagai hasil konkret, pengabdian ini telah dimuat di 23 rilis berita media elektronik seperti berikut;

1. https://jatiminstitute.com/patu hi-protokol-kesehatan-covid19-pembukaan-pmm-mitradosen-2021-kelurahanbumiayu-sukses-digelar/;

2. https://www.malanghub.com/ news/patuhi-protokolkesehatan-covid-19pembukaan-pmm-mitradosen-2021-kelurahanbumiayu-sukses-digelar;

3. https://news.limadetik.com/ke pala-kelurahan-bumiayusambut-baik-kegiatan-pmm- 
mitra-dosen-2021-fh-umm-

di-kelurahan-bumiayu/;

4. https://jatiminstitute.com/kep

ala-kelurahan-bumiayusambut-baik-kegiatan-pmmmitra-dosen-2021-fh-ummdi-rw-01-rt-11-kelurahanbumiayu/;

5. https://news.limadetik.com/pa tuhi-protokol-kesehatancovid-19-pembukaan-pmmmitra-dosen-2021-kelurahanbumiayu-sukses-digelar/;

6. https://hukum.umm.ac.id/id/b erita/patuhi-protokolkesehatan-covid-19pembukaan-pmm-mitradosen-2021-kelurahanbumiayu-sukses-digelar.html;

7. https://www.malanghub.com/ news/pmm-mitra-dosenumm-and-umkm-di-bumiayubersinergi-kembangkanbisnis-di-era-pandemi;

8. https://www.indonesiana.id/re $\mathrm{ad} / 147361 /$ pembukaan-pmmmitra-dosen-2021-kelurahanbumiayu-sukses-digelar;

9. https://www.indonesiana.id/re $\mathrm{ad} / 147362 /$ mahasiswafakultas-hukum-universitasmuhammadiyah-malangkunjungi-kantor-kelurahanbumiayu;

10. https://jurnalpost.com/patuhiprotokol-kesehatan-covid-19pembukaan-pmm-mitradosen-2021-kelurahanbumiayu-suksesdigelar/22357/;
11. https://jurnalpost.com/kepalakelurahan-bumiayu-sambutbaik-kegiatan-pmm-mitradosen-2021-fh-umm-di-rw01-rt-11-kelurahanbumiayu/22354/;

12. https://jatiminstitute.com/pen yebaran-brosur-minumancangloh-di-kecamatanlowokwaru-oleh-mahasiswafakultas-hukum-universitasmuhammadiyah-malang/;

13. https://jatiminstitute.com/mah asiswa-fakultas-hukum-ummperkenalkan-produkminuman-cangloh-dikelurahan-dinoyo-malang/;

14. https://jatiminstitute.com/pent ingnya-sertifikasi-halalmahasiswa-fh-umm-beriedukasi-jaminan-produkhalal-pada-tenaga-kerja-cvcaraka/;

15. https://news.limadetik.com/m ahasiswa-fakultas-hukumumm-perkenalkan-produkminuman-cangloh-dikelurahan-dinoyo-malang/;

16. https://news.limadetik.com/pe nyebaran-brosur-minumancangloh-di-kecamatanlowokwaru-oleh-mahasiswafakultas-hukum-universitasmuhammadiyah-malang/;

17. https://news.limadetik.com/pe ntingnya-sertifikasi-halalmahasiswa-fh-umm-beriedukasi-jaminan-produkhalal-pada-tenaga-kerja-cvcaraka/; 
18. https://www.malanghub.com/ news/mahasiswa-fakultashukum-umm-perkenalkanproduk-minuman-cangloh-dikelurahan-dinoyo-malang;

19. https://www.malanghub.com/ news/pentingnya-sertifikasihalal-mahasiswa-fh-ummberi-edukasi-jaminan-produkhalal-pada-tenaga-kerjacv.caraka;

20. https://www.malanghub.com/ news/penyebaran-brosurminuman-cangloh-dikecamatan-lowokwaru-olehmahasiswa-fakultas-hukumuniversitas-muhammadiyahmalang;

21. https://www.indonesiana.id/re ad/147362/mahasiswafakultas-hukum-universitasmuhammadiyah-malangkunjungi-kantor-kelurahanbumiayu;

22. https://www.indonesiana.id/re $\mathrm{ad} / 147478 /$ mahasiswa-fhumm-beri-edukasi-jaminanproduk-halal-pada-tenagakerja-cv-caraka;

23. https://www.indonesiana.id/re $\mathrm{ad} / 147482 /$ mahasiswa-fhumm-perkenalkan-minumancangloh-di-dinoyo-malang

\section{SIMPULAN}

Sebagai kesimpulan solusi yang ditawarkan untuk Mitra kami yaitu CV. Caraka Abadi sebagai produsen Cangloh adalah didapatnya sertifikasi dan logo halal dari MUI untuk bisa disertakan dalam setiap produk dan promosi mereka. Dan hasil tersebut saat ini sudha mendekati kenyataan karena berkas sudah di submit dan sudah disetujui tinggal menunggu penerbitan sertifikatnya.

\section{DAFTAR PUSTAKA}

Al-Fatih, S., \& Aditya, Z. A. (2017). Perbandingan Hukum Fatwa Halal di Beberapa Negara (Kajian Yuridis Fatwa Halal MUI dan Fatwa Halal dari Lembaga Lain di Luar Negeri). Prosiding KNPHI Unair.

Al-Fatih, Sholahuddin, \& Aditya, Z. F. (2019). ANALISIS YURIDIS KEDUDUKAN HUKUM LEMBAGA PEMBERI FATWA HALAL DI BEBERAPA NEGARA. Jurnal Wacana Hukum, 25(1), 68-79.

https://doi.org/10.33061/1.jwh.2 019.25.1.3033

Al-Fatih, Sholahuddin, \& Esfandiari, F. (2020). Halal Food in South East Asia: Are We Looking Forward? Atlantis Press, 121(Inclar 2019), 166-169. https://doi.org/10.2991/aebmr.k. 200226.034

Anonim. (2021). Wawancara dengan Owner CV. Caraka Abadi.

Awaludin, L. (2018). Makanan Halal Dalam Perspektif Islam. 12(2), 264-348.

BPS. (2020). Official News Statistics May 5, 2020, .

https://www.bps.go.id/website/ materi_ind/materiBrsInd20200505115439.pdf

Esfandiari, F., \& Al-Fatih, S. (2021). Pendampingan Akad dan Sertifikasi Halal MUI serta Edukasi Jaminan Produk Halal 
pada Minuman Cangloh di Mergosono Kota Malang. Dedikasi Hukum, 1(2), 1-13. https://doi.org/https://doi.org/10 .2229/jdh.v1i2.17607

Hidayat, A. S., \& Siradj, M. (2015). Sertifikasi Halal dan Sertifikasi Non Halal pada Produk Pangan Industri. Jurnal Ahkam, 15(2), 200.

Irwansyah. (2020). Penelitian Hukum: Pilihan Metode \& Praktik Penulisan Artikel (A. Yunus (ed.)). Mirra Buana Media.

LPPOM MUI. (2008). Panduan Umum Sistem Jaminan Halal. LPPOM MUI.

Sa'diyah, H. (2017). Produk Pangan Bersertifikat Halal Masih Minim. Republika.Co.Id.

Salam, S., Suhartono, R. M., \& La Dee, M. (2021). Construction of the Concept of Building Populist Economic Law. Audito Comparative Law Journal (ACLJ), 2(3), 119-130. https://doi.org/10.22219/aclj.v2i 3.17494

Sayekti, N. W. (2014). Jaminan Produk Halal dalam Perspektif Kelembagaan. Jurnal Ekonomi Dan Kebijakan Publik, 5(2), 193-209.

Soekanto, S. (2014). Pengantar Penelitian Hukum. UI-Press.

Syafrida. Hartati, R. (2019). MEWUJUDKAN PERLINDUNGAN HUKUM DAN JAMINAN KEPASTIAN HAK KONSUMEN MUSLIM TERHADAP PRODUK HALAL (SUATU KAJIAN AJARAN GUSTAV RADBRUCH). Jurnal Hukum Replik, 7(1), 38-54. https://doi.org/10.1017/CBO978
1107415324.004

Wiryani, F., Najih, M., \& Haris, A. (2018). JURIDICAL ANALYSIS ON CONSUMER PROTECTION IN SAFE AND HALAL. Dinamika Hukum, 18(1), 20-29.

https://doi.org/http://dx.doi.org/ 10.20884/1.jdh.2018.18.1.1586

Yuliana, T. (2016). "Sinergi antara Pemerintah Kota dengan Lembaga Zakat dalam Meningkatkan Kesejahteraan Masyarakat" (Studi di Rumah Zakat, YDSF dan Badan Amil Zakat Nasional Kota Malang). Universitas Brawijaya, Malang. Zain, H. A., Wiryani, F., \& Hasanah, I. (2021). Kesadaran Hukum Sertifikasi Halal Pelaku Usaha Rumah Makan Di Kota Malang. Indonesia Law Reform Journal, 1(1), 122-142.

https://doi.org/10.22219/ilrej.v1 i1.16130 